\title{
Género / Gender
}

https://doi.org/10.21814/uminho.ed.36.32

\section{Vera Duarte}

Universidade da Maia (ISMAI) e CICS.NOVA - Centro Interdisciplinar de Ciências Sociais, polo Universidade do Minho, Portugal 



\section{Género}

Para a maioria das crianças, ser rapaz ou rapariga é algo que parece perfeitamente natural. À nascença são designados do sexo masculino ou feminino com base nas suas características físicas (i.e., sexo ou género atribuído). Mas quando falamos da construção da sua identidade de género, que se dá nos primeiros anos de vida e é feita pela apropriação dos modelos culturalmente dominantes do que "é ser rapaz" ou "ser rapariga” (i.e., estereótipos de género) (Beal, 1994), o processo parece complexificar-se. Embora o comportamento específico de género de uma criança tenda a alinhar-se com o seu género atribuído, por força do processo de socialização diferencial que muda no espaço e no tempo (i.e., expressões de género), a sensação interna de ser rapaz, rapariga, os dois ou nenhum não pode ser alterada. 0 género é uma das categorias centrais que organiza o mundo social das crianças.

Como categoria analítica, o género é uma construção sociocultural que nos permite entender como se constroem as relações sociais e pensar as pessoas como entidades políticas, sociais e culturais, superando os determinismos da categoria de sexo. Neste sentido, percebemos que definir o conceito de género é uma tarefa complexa.

Impõe-se, assim, a distinção entre os conceitos de sexo e género. 0 termo sexo pertence ao domínio da biologia e diz respeito às características genéticas, anatómicas e fisiológicas que diferenciam os rapazes/homens das raparigas/mulheres (note que estas características biológicas não são mutuamente exclusivas). 0 conceito de género inscreve-se no domínio da cultura e remete para o conjunto socialmente construído de papéis e responsabilidades associados aos rapazes/raparigas, homens/mulheres, incorporadas ao longo do processo de socialização, que fornecem elementos indispensáveis para a perceção e compreensão do próprio corpo e para a construção das noções de eu e do outro (Amâncio, 2003).

O género é um elemento constitutivo das relações sociais e constituinte de identidades pessoais e sociais, o aprofundamento da sua concetualização passa também por perceber os seus principais componentes, que se interligam entre si (Connell, 2009): 
(a) Sistema de Género - sistema social que determina as relações de género, relações baseadas na distribuição desigual de poder entre homens e mulheres, e que se institucionaliza através dos sistemas educativo, social, político, cultural, económico, religioso;

(b) Sistema simbólico - sistema de símbolos culturalmente disponíveis que evocam representações de género onde o masculino se constitui como o referente dominante na maioria das sociedades ao longo dos séculos, o que reforça os estereótipos, os papéis, as ideologias e identidades de género;

(c) Estereótipos de género - crenças amplamente partilhadas pela sociedade sobre o que significa ser rapaz/homem ou ser rapari$\mathrm{ga} / \mathrm{mulher}$, estabelecendo aquilo que é esperado de cada um dos sexos relativos aos traços de personalidade, às características físicas, aos papéis desempenhados ou às atividades profissionais;

(d) Papéis de género - conjunto de normas de ação e comportamento atribuídas a rapazes / homens e raparigas / mulheres e classificados como tipicamente masculinas e femininas;

(e) Identidade de género - processo complexo de definições sociais recebidas e percecionadas que implicam a tomada de consciência individual da pertença (ou não) a uma categoria de género e o desenvolvimento de atitudes para com os grupos de género;

(f) Expressões de género - a forma como uma criança (ou adulto) mostra externamente a sua identidade de género pela escolha de atividades, comportamentos, roupas, penteados, nomes / apelidos, entre outros, que estão associados ao que uma sociedade aceita como normativo para cada género.

Nas Ciências Sociais, a preocupação teórica e a emergência do conceito de género são recentes. Uma preocupação ausente das grandes Teorias Sociais, formuladas entre os séculos XVIII e o início do século XX, marcadas, essencialmente, pelo androcentrismo. Foi na década de 1970, do século XX, que surgiu um contexto mais favorável à sua expressão, por força do intenso debate gerado pelos feminismos da segunda vaga. A distinção entre sexo e género, proposta por Ann Oakley em 1972, mas já sugerida por Simone de Beauvoir, em 1949, na sua famosa formulação "não se nasce mulher, antes torna-se mulher", surgiu da necessidade de explicar que as diferenças 
observadas entre os sexos não se justificam simplesmente pela pertença da pessoa a uma categoria biológica, mas que resultam, sobretudo, de construções culturais que engendram representações e estereótipos sobre os géneros. Deste modo, tem sido legitimado um sistema de relações sociais de dominação e subordinação marcado, historicamente, por desigualdades de poder ao nível material e simbólico, como demonstra Bourdieu, no seu livro Dominação Masculina.

É em torno da distinção e relação entre sexo e género que confluem grande parte das discussões concetuais, teóricas e políticas desenvolvidas, nem sempre facilmente conciliáveis entre si.

(1) Género e biologia - agrega teorias que defendem que os comportamentos de rapazes / homens e raparigas / mulheres são resultado das suas diferenças, determinações e predisposições físicas, biológicas e psicológicas. Uma diferença que é estática, bipolar e categorial;

(2) Socialização e aprendizagem dos papéis de género - concentra teorias (i.e., aprendizagem social, teorias cognitivas e desenvolvimentistas) que defendem que a criança nasce com um sexo biológico e desenvolve-se com um género social, cujos papéis e expressões são apre(e)ndidos no processo de socialização na infância;

(3) Enfoque no género enquanto estrutura social - traz a questão do poder, da estratificação social e da discriminação para a discussão. 0 princípio analítico de que não há apenas uma diferenciação socialmente construída, mas também uma desigualdade social inerente, transforma o género num dos elementos que condiciona e hierarquiza a posição social das crianças, a par de outros como a classe social, raça e etnia, nacionalidade, idade, profissão ou religião (Connell, 2009);

(4) Construção social do sexo e do género - reúne abordagens mais críticas e reflexivas (influenciadas pelos construcionismos sociais, os feminismos pós-modernos e pós-estruturalistas e as teorias queer), que recusam a possibilidade de discursos universalizantes e generalizáveis acerca do género, rejeitando o sistema binário de género e sustentando que as características sociais são ativamente criadas e não são nem biologicamente inerentes, 
nem permanentemente socializadas ou estruturalmente predeterminadas. 0 género passa a ser um ato performativo (Butler, 1990). Um sistema não binário inclui identidades de género que não são integral e exclusivamente masculinas ou femininas. As pessoas podem identificar-se com dois ou mais géneros (bi-gender), sem género (agender), ter uma identidade de género fluida (gender-fluid) ou ser de outro género (third-gender).

Ir além dos estudos sobre as diferenças entre rapazes e raparigas nas diferentes fases de desenvolvimento, permitirá explicar as diversas posições que as crianças ocupam numa sociedade genderizada e as suas experiências em relação à performatividade de género, contribuindo para a construção de contra-narrativas que questionem o status quo e diminuam as persistentes desigualdades (de género).

\section{Gender}

For most children, being a boy or girl is something that seems perfectly natural. At birth they are designated male or female based on their physical characteristics (e.g., sex or assigned gender). But when we talk about the construction of their gender identity, which occurs early in life, and is made by the appropriation of culturally dominant models of what "it means to be a boy" or "to be a girl" (e.g., gender stereotypes) (Beal, 1994), the process seems to become more complex. Although a child's gender-specific behaviour tends to align with his assigned gender, because of the differential socialization process which changes in space and time (e.g., gender expressions), the internal feeling of being a boy, or a girl, both or neither cannot be changed. Gender is one of the central categories that organize the social world of children.

As an analytical category, gender is a socio-cultural construct that allows us to understand how social relationships are built and to think of people as political, social and cultural entities, overcoming the determinisms of the sex category. In this sense, we realize that defining the concept of gender is a complex task.

Thus, a distinction between the concepts of sex and gender is necessary. The term sex belongs to the domain of biology and refers to the genetic, anatomical and physiological characteristics that differentiate boys/men from girls/women (note that these biological characteristics are not mutually exclusive). The concept of gender is a part of the field of culture and 
refers to the socially constructed sets of roles and responsibilities associated with boys / girls, men / women, incorporated throughout the socialization process, which provide essential elements for the perception and understanding of own body and for the construction of the notions of self and the other (Amâncio, 2003).

Gender is a constitutive element of social relations and a constituent of personal and social identities. In this sense, the deepening of its conceptualization also involves perceiving its main components and the way they are interconnected with each other (Connell, 2009):

(a) The Gender System is a social system that determines gender relations, i.e. relationships based on the unequal distribution of power between men and women, and that is institutionalized through educational, social, political, cultural, economic and religious systems;

(b) The Symbolic System is a system of symbols that are culturally available and evoke gender representations where, over centuries, the masculine constitutes the dominant referent in most societies, and reinforces stereotypes, roles, ideologies and gender identities;

(c) Gender stereotypes are beliefs widely shared by society about what it means to be a boy / man or to be a girl / woman, establishing what is expected of each gender regarding personality traits, physical characteristics, roles played or professional activities;

(d) Gender roles are a set of norms of actions and behaviours attributed to boys / men and girls / women and classified as typically male and female;

(e) Gender identity corresponds to a complex process of received and perceived social definitions that imply the individual awareness of belonging (or not) to a gender category and the development of attitudes towards gender groups;

(f) Gender expressions are the ways in which a child (or adult) shows gender identity externally through the choices of activities, behaviours, clothes, hairstyles, names / nicknames, among others, 
which are associated with what a society accepts as normative for each gender.

In Social Sciences, a theoretical concern and the emergence of the concept of gender are recent. It is a concern that is absent from the great Social Theories, formulated between the 18th and early 20th centuries, which are marked, essentially, by androcentrism. It was in the 1970s that a more favorable context for its expression emerged, because of the intense debate generated by the feminists of the second wave. The distinction between sex and gender, proposed by Ann Oakley in 1972, but already suggested by Simone de Beauvoir's remark, in 1949, that "women are not born, but made", arose from the need to explain that the differences observed between the sexes are not justified simply by the person's belonging to a biological category, but that result mainly from cultural constructions that engender representations and stereotypes about gender. In this way, a system of social relations of domination and subordination has been marked, historically, by inequalities of power at the material and symbolic level, as shown by Bourdieu, in his book Masculine Domination.

It is the distinction and relationship between sex and gender that generate much of the conceptual, theoretical and political discussions, not always easily reconcilable with each other:

(1) Gender and biology aggregates theories that argue that behaviours of males and females are the result of their physical, biological and psychological differences and predispositions. This is a difference that is static, bipolar and categorical;

(2) Socialization and learning of gender roles concentrate theories (e.g. social learning, cognitive and developmental theories) that argue that the child is born with a biological sex and develops a social gender, whose roles and expressions are perceived and learned in the childhood socialization process;

(3) The focus on gender as a social structure brings the issue of power, social stratification and discrimination to the discussion. The analytical principle that there is not only a socially constructed differentiation, but also an inherent social inequality, turns gender into one of the elements that conditions and hierarchizes the social position of children, alongside others such as social 
class, race and ethnicity, nationality, age, profession or religion (Connell, 2009);

(4) The social construction of sex and gender brings together more critical and reflective approaches (influenced by social constructionism, postmodern and post-structuralist feminisms and queer theories), which reject the possibility of the universalizing and generalizable discourses about gender, rejecting the binary gender system and maintaining that social characteristics are actively created and are neither biologically inherent, nor permanently socialized or structurally predetermined. Gender becomes a performative act (Butler, 1990). A non-binary system includes gender identities that are not entirely and exclusively male or female. People can identify with two or more genders (bi-gender), without gender (agender), have a fluid gender identity (gender-fluid) or be of another gender (third-gender).

Going beyond studies on the differences between boys and girls at different stages of development will allow the explanation of the different positions that children occupy in a gendered society and their experiences in relation to gender performance, contributing to the construction of counter-narratives that question the status quo and reduce persistent (gender) inequalities.

\section{Referências / References}

Amâncio, L. (2003). O género no discurso das Ciências Sociais. Análise Social, XXXVIII (168), 687-714

Beal, C. (1994). Boys and Girls: the Development of Gender Roles. New York: McGraw-Hill.

Butler, J. (1990). Gender Trouble: Feminism and the Subversion of Identity. New York: Routledge

Connell, R. (2009). Gender: in world perspective. Cambridge: Polity Press. 